\title{
Ocena najnowszych trendów leczenia nowotworów układu moczowego prezentowanych na Konferencji ASTRO 2015, San Antonio, USA
}

\section{Assessment of the latest trends in the treatment of urological cancers presented at the ASTRO 2015 Conference, San Antonio, USA}

\author{
Piotr Milecki ${ }^{1,2}$ \\ ${ }^{1}$ Zakład Radioterapii I i Oddział Radioterapii Onkologicznej I, Wielkopolskie Centrum Onkologii w Poznaniu \\ ${ }^{2}$ Katedra i Zakład Elektroradiologii, Uniwersytet Medyczny im. Karola Marcinkowskiego w Poznaniu
}

\section{Streszczenie}

W 2015 roku w San Antonio, USA odbyła się już kolejna, tj. 56 konferencja naukowa Amerykańskiego Towarzystwa Radioterapii Onkologicznej (ASTRO). W jej trakcie szczególną uwagę poświęcono doniesieniom naukowym dotyczącym leczenia nowotworów urologicznych. Z praktycznego punktu widzenia bardzo istotnymi były sesje dotyczące możliwości leczenia zaawansowanego raka pęcherza moczowego szczególnie $\mathrm{u}$ chorych w podeszłym wieku. Obecnie wielu chorych z tym nowotworem nie otrzymuje jakiegokolwiek radykalnego leczenia poza przekazaniem do poradni paliatywnej. Podczas gdy u takich chorych z całkiem dobrym powodzeniem można zastosować radioterapię, która wielu z nich może doprowadzić do wyleczenia lub opóźnienia progresji choroby. Wprowadzenie leczenia napromienianiem w tej grupie chorych powinno być jednym z głównych priorytetów leczenia raka pęcherza moczowego. Należy nadmienić, że wyniki leczenia tego nowotworu w Polsce należą do jednych z najgorszych w EU.

\footnotetext{
Abstrakt

Piotr Milecki

Zakład Radioterapii I i Oddział Radioterapii Onkologicznej I

Wielkopolskie Centrum Onkologii, ul. Garbary 15, 61-866 Poznań, Polska

e-mail: piotr.milecki@wco.pl
}

In 2015, the 56th conference of the American Society of Therapeutic Radiotherapy Oncology (ASTRO) was held in San Antonio, USA. During the conference special attention was focused on the treatment of urological cancers, especially prostate cancer and bladder cancer. Generally, treatment of patients with lowrisk and intermediate-risk prostate cancer has focused on the survival and other very important endpoints which is the quality of life. Randomized clinical trials which were presented during the conference showed that long-term androgen deprivation therapy combined with radiotherapy is associated with survival benefit for the group of patients with high-risk prostate cancer in spite of using high-dose radiotherapy treatment.

Very important from daily practice perspective, were the sessions on the possibility of treating patients at older age who usually have significant comorbidities. According to data from many epidemiological studies, significant percentage of those patients did not receive any radical therapy apart from palliative treatment. Radiotherapy in these cases could be the only possible method of radical therapy. It is worth to mention that 
results of therapy of advanced bladder cancer in Poland are among the worst in Europe.

Stowa kluczowe: rak gruczołu krokowego, rak pęcherza moczowego, radioterapia, terapia hormonalna

Keywords: prostate cancer, bladder cancer, radiotherapy, androgen deprivation therapy

\section{Rak stercza}

Zmiany demograficzne związane ze starzeniem się społeczeństw, w tym także polskiego powodują, że każdego roku wzrasta liczba zachorowań na raka stercza [1]. W związku z tym, poszukiwanie metod poprawy wyników leczenia jest wyzwaniem zarówno dla urologów jak i onkologów. W czasie konferencji ASTRO, która odbyła się w San Antonio w 2015 roku, w dużej części dotyczącej leczenia raka stercza, poświęcona została nowym sposobom frakcjonowania dawki jak również eskalacji dawki. Rozwój technologiczny, który dokonał się w ostatnim okresie spowodował, że RT osiągneła poziom efektywności porównywalny do leczenia operacyjnego, a w niektórych sytuacjach klinicznych RT wręcz może być bardziej efektywną metodą leczenia RS.

Jednym z kluczowych randomizowanych badań klinicznych, którego wyniki przedstawiono podczas konferencji ASTRO, było badanie DART o1/o5. Grupa badaczy z Hiszpanii przeprowadziła randomizowane badanie kliniczne, w którym porównano efektywność krótkotrwałej hormonoterapii do terapii długotrwałej u chorych z diagnozowanym RS w wysokim oraz pośrednim ryzyku progresji, w przypadku kiedy zastosowano wysokodawkową RT. Podstawowych przesłanek do przeprowadzenia powyższego badania dostarczyły wcześniejsze wyniki randomizowanych badań klinicznych. W szeregu dotychczas przeprowadzonych badań porównano wpływ dodania leczenia hormonalnego do klasycznej RT na wyniki leczenia w sytuacji kiedy stosowano standardowe dawki napromieniania (RTOG 8531, RTOG 8610, RTOG 9202, EORTC - Bolla) [2-9]. We wszystkich tych badaniach stwierdzono istotną statystycznie poprawę przeżyć całkowitych w przypadku skojarzenia RT z hormonoterapią. Jednocześnie w tym samym okresie szereg innych opublikowanych randomizowanych badań klinicznych udowodniło, że eskalacja dawki w RT znacząco poprawia wyniki leczenia RS. W związku z tym w badaniu DART 01/05 badacze postanowili odpowiedzieć na pytanie czy długo-trwała (LTAD) ma przewagę nad krótko-trwałą (STAD) w przypadku wysoko-dawkowej RT w grupie pośredniego i wysokiego ryzyka RS? Głównymi punktami końcowymi badania były: czas przeżycia bez wznowy biochemicznej - według kryterium Phoenix definition i toksyczność leczenia (klasyfikacja odczynów popromiennych RTOG/EORTC i CTC AE). Do dalszych punktów końcowych zaliczono przeżycie całkowite, przeżycie swoiste dla raka, przeżycie wolne od przerzutów. W ramieniu krótkotrwałej hormonoterapii stosowano powyższe leczenie przez okres 4 miesięcy, a w grupie z długotrwałą hormonoterapią przez 24 miesiące. W obu ramionach jako minimalną dawkę RT przyjęto 76 Gy. Do badania zakwalifikowano 355 chorych, których leczono w okresie od 2005 roku do 2010 roku. W podsumowaniu autorzy wykazali, że pomimo tego, że stosowano minimalną dawkę przekraczającą 76 Gy (średnio 78 Gy) nadal obserwuje się istotnie statystyczną różnicę w wynikach pomiędzy badanymi grupami chorych. W grupie chorych, u których stosowano długotrwale hormonoterapię 5 letnie przeżycie bez nawrotu biochemicznego uzyskano u 88\% wszystkich leczonych chorych. Należy nadmienić, że generalnie pomiędzy badanymi grupami nie odnotowano istotnych różnic w powikłaniach ze strony przewodu pokarmowego oraz układu moczowego. Wyniki powyższego badania wskazują, że pomimo stosowania nowoczesnej wysokodawkowej RT nadal dodanie długotrwałej hormonoterapii pozwala uzyskać zysk w przeżyciach całkowitych i takie leczenie powinno być nadal standardowym postępowaniem. Pewnymi punktami słabymi powyższego badania był relatywnie krótki czas obserwacji (5-lat) oraz brak stosowania techniki IGRT (ang. image guided radiation therapy). Okres obserwacji chorych w badaniu DART 01/o5 był relatywnie krótki i w związku z tym pojawia się pytanie jak mogą wygladać wyniki w przypadku długoterminowej obserwacji i czy nadal korzystny efekt terapii hormonalnej byłby wówczas utrzymany. Odpowiedzi na powyższe pytania podjęto w badaniu RTOG 9202, w którym oceniono wyniki leczenia po okresie obserwacji wynoszącym ponad 20 lat. Konstrukcja badania RTOG 9202 była praktycznie bardzo podobna do badania DART 01/o5 z tym, że w tym badaniu nie stosowano eskalacji dawki w RT. Wyniki badania RTOG 9202 wskazują, że nawet po długim (20 lat 
obserwacji) okresie od zakończenia leczenia pozytywny efekt hormonoterapii jest zachowany, a co więcej zysk z leczenia skojarzonego ulega zwiększeniu wraz z upływem czasu i jest większy aniżeli w krótkim czasie od zakończenia leczenia.

Podsumowując, ostatnie doniesienia z konferencji ASTRO wskazują na celowość stosowania leczenia skojarzonego, zwłaszcza w grupie chorych wysokiego ryzyka progresji RS. Powyższe ma szczególne znaczenie w przypadku stosowania nawet wysokiej dawki RT stanowiącej obecnie standard w RS z grupy wysokiego ryzyka progresji.

Kolejnym ważnym, z punktu widzenia codziennej praktyki klinicznej, było przedstawione badanie kliniczne RTOG 0126. W badaniu powyższym dokonano porównania wyników leczenia napromienianiem chorych w RS, w przypadku kiedy zastosowano RT o podwyższonej dawce do leczonych chorych niższą dawką. Do głównych celów badania należała próba odpowiedzi, czy zaaplikowanie dawki 79,2 Gy w porównaniu do dawki 70,2 Gy prowadzi do poprawy przeżyć całkowitych, przeżyć bez wznowy biochemicznej, przeżyć swoistych dla RS i przeżyć wolnych od wystąpienia przerzutów odległych w grupie chorych o pośrednim ryzyku progresji nowotworu? Do analizy zakwalifikowano 1520 chorych, których leczono klasyczną techniką RT (3DCRT) lub techniką IMRT. Badacze stwierdzili brak statystycznie istotnej różnicy w przeżyciach całkowitych oraz swoistych dla RS pomiędzy badanymi ramionami zarówno po 5 letnim jak i 10 letnim okresie obserwacji. Po okresie 5 lat odnotowano zaledwie $0,5 \%$ różnicę w przeżyciach swoistych dla $\mathrm{RS}$, a po obserwacji wynoszącej ponad 10 lat około $2 \%$. Należy nadmienić, że dla obu punktów końcowych nie stwierdzo istotnej statystycznie różnicy. Natomiast różnica pomiędzy ramionami w przeżyciach bez nawrotu biochemicznego w okresie 10 lat obserwacji wyniosło 17\%, oczywiście w grupie leczonych wyższą dawką. Niestety uzyskany zysk w kontroli biochemicznej nie przełożył się na zysk w przeżyciach całkowitych, czy swoistych dla RS. Natomiast poziom powikłań popromiennych zarówno w odniesieniu do przewodu pokarmowego, jak i układu moczowego, nie różnił się w sposób istotny pomiędzy badanymi grupami chorych. W podsumowaniu autorzy badania wskazali, że eskalacja dawki do 79.2 Gy w porównaniu do dawki 70.2 Gy w grupie chorych o pośrednim ryzyku nie wpływa na przeżycie całkowite i przeżycie swoiste dla RS, a jedynie poprawia efektywność miejscową, wydłuża czas wolny do przerzutów odległych i czas do wystąpienia wznowy biochemicznej. Ponadto eskalacja dawki w nieznacznym stopniu zwiększa ryzyko powikłań stopnia $2 \geq$ ze strony przewodu pokarmowego i układu moczowego. W związku z tym, można pokusić się o dodatkowy komentarz, wskazujący na to, że eskalacja dawki nie jest bezwzględnie wymagana u każdego chorego w grupie pośredniego ryzyka progresji. Potencjalny zysk może nie być oczekiwany u chorych w wieku po 70 roku życia, w stopniu złośliwości komórkowej Gleason $<4(3+4),<50 \%$ obecnego materiału nowotworowego w materiale biopsyjnym i kiedy stwierdza się obecność dodatkowych schorzeń (ang. Charlson morbidity index).

Następnym badaniem klinicznym z grupy badających eskalację dawki było badanie przedstawione przez naukowców ze Stanów Zjednoczonych; RTOG 0415, oceniające wyniki leczenia w grupie chorych o pośrednim ryzyku progresji w przypadku zastosowania (73,8 Gy) standardowej dawki promieniowania frakcjonowanej konwencjonalnie lub napromieniania z zastosowaniem umiarkowanego hipofrakcjonowania (2,5 Gy do dawki całkowitej $70 \mathrm{~Gy} / 28$ frakcji). Badacze zadali pytanie: czy w odniesieniu do przeżyć bez wznowy biochemicznej, przeżyć swoistych dla RS oraz objawów ubocznych można oczekiwać zysku wynikającego z zastosowania wyższej dawki frakcyjnej w radioterapii? W analizie końcowej powyższego badania stwierdzono, że w hipofrakcjonowana RT nie jest gorsza aniżeli klasycznie frakcjonowana.

\section{Rak pęcherza moczowego}

W sesji edukacyjnej szczególną uwagę zwrócono na bardzo ważny problem kliniczny, jakim jest suboptymalne leczenie raka pęcherza moczowego. Mianowicie wraz ze starzeniem się społeczeństwa wzrasta odsetek chorych, u których stwierdza się znaczne nasilenie obecności schorzeń współistniejacych, które w znaczący sposób ograniczają zastosowanie leczenia operacyjnego. Prowadzi to niestety w wielu sytuacjach do odstąpienia od radykalnego leczenia operacyjnego, a jednocześnie nie proponuje się chorym alternatywnej metody jaką mogłaby być RT. Podkreślenia wymaga także fakt, że intensywność objawów ubocznych związanych z RT czy radiochemioterapią generalnie nie odbiega znacząco od tych występujących po leczeniu operacyjnym. Niestety nie posiadamy randomizowanego badania klinicznego porównującego opcję 
leczenia oszczędzającego pęcherz moczowy z wykorzystaniem tzw. Trimodality Treatment (zabieg resekcji przezcewkowej + chemioradioterapia) do radyklanej cystektomii. Z tego też względu należy zwiększyć nacisk na interdyscyplinarne podejście do podejmowania decyzji w leczeniu raka pęcherza moczowego, w którym RT jest nadal nie docenianą metodą leczenia, a zwłaszcza w grupie chorych, u których występują obciążenia schorzeniami dodatkowymi dyskwalifikującymi z leczenia operacyjnego [10-15].

\section{Piśmiennictwo / References}

[1] Paulson DF, Lin GH, Hinshaw L, Stephani S: Radical surgery versus radiotherapy for adenocarcinoma of the prostate. J Urol, 1982;128:502-4.

[2] Zietman AL, DeSilvio ML, Slater JD i wsp: Comparison of conventional dose vs high-dose conformal radiation therapy in clinically localized adenocarcinoma of the prostate: a randomized controlled trial. JAMA, 2005; 294: 1233-9.

[3] Kupelian PA, Katcher J, Levin HS, Klein EA: Staging T1-2 prostate cancer: a multivariate analysis of factors affecting biochemical and clinical failures after radical prostatectomy. Int $J$ Radiat Oncol Biol Phys, 1997; 37:1043-52.

[4] Milecki P, Kwias Z, Martenka P: Radiotherapy combined with hormonal therapy (RT-HT) in prostate cancer patients with low, intermediate, and high-risk of biochemical recurrence: perspective and therapeutic gain analysis. Neoplasma, 2007; 54: 7-15.

[5] Milecki P, Kwias Z: Hormonal therapy combined with radiotherapy in locally advanced prostate cancer. Rep Pract Oncol Radiother, 2002;7:157-63.

[6] Crook J, Ludgate C, Malone S i wsp: Report of a multicenter Canadian phase III randomized trial of 3 months vs. 8 months neoadjuvant androgendeprivation before standard-dose radiotherapy for clinically localized prostate cancer. Int J Radiat Oncol Biol Phys 2004;60:15-23.

[7] D’Amico AV, Manola J, Loffredo M i wsp: 6-month androgen suppression plus radiation therapy vs radiation therapy alone for patients with clinically localized prostate cancer: A randomized controlled trial. JAMA 2004;292:821-27.

[8] Bolla M, Gonzalez D, Warde P i wsp: Improved survival in patients with locally advanced prostate cancer treated with radiotherapy and gosorelin. N Engl J Med, 1997; 337:295-300.

[9] Hanks GE, Pajak TF, Porter A i wsp: Phase III trial of long-term adjuvant androgen deprivation after neoadjuvant hormonal cytoreduction and radiotherapy in locally advanced carcinoma of the prostate: the Radiation Therapy Oncology Group Protocol 92-02. J Clin Oncol, 2003;21: 3972-8.

[10] Coppin CM, Gospodarowicz MK, James K et al. Improved local control of invasive bladder cancer by concurrent cisplatin and preoperative or definitive radiation. The National Cancer Institute of Canada Clinical Trials Group. J Clin Oncol 1996; 14: 2901-2907.

[11] Hoskin PJ, Rojas AM, Bentzen SM, Saunders MI. Radiotherapy with concurrent carbogen and nicotinamide in bladder carcinoma. J Clin Oncol 2010; 28: 4912-4918.

[12] James ND, Hussain SA, Hall E et al. Radiotherapy with or without chemotherapy in muscle-invasive bladder cancer. N Engl J Med 2012; 366: 1477-1488.

[13] Rödel C, Grabenbauer GG, Kühn R et al. Combined-modality treatment and selective organ preservation in invasive bladder cancer: long-term results. J Clin Oncol 2002; 20: 3061-3071.

[14] Shipley WU, Zietman AL, Kaufman DS et al. Selective bladder preservation by trimodality therapy for patients with muscularis propria-invasive bladder cancer and who are cystectomy candidates-the Massachusetts General Hospital and Radiation Therapy Oncology Group experiences. Semin Radiat Oncol 2005; 15: 36-41.

[15] Weiss C, Wolze C, Engehausen DG et al. Radiochemotherapy after transurethral resection for high-risk T1 bladder cancer: an alternative to intravesical therapy or early cystectomy? J Clin Oncol 2006; 24: 2318-2324. 